UDC 930.1

Davit MOSINYAN

\title{
CAN THERE BE A CREDIBLE PHILOSOPHY OF HISTORY?
}

\begin{abstract}
A lot of different historical issues were discussed during many centuries. As a result, the philosophy of history was established as an independent academic discipline. However, nowadays there are so many philosophies of history that we have to ask ourselves where this development leads us to, and whether they have anything positive to give to science. The question is as follows: "Can there be a credible philosophy of history?". Nevertheless, we still need to find out the significance of its credibility. To perform this task, we need to examine the very concept of the philosophy of history and to study the history of the philosophy of history.
\end{abstract}

Keywords: history, historiography, historical research, historical text, philosophy of history, credibility, metahistory, discipline.

Notoriously, history has not always existed. The history emerges from the consciousness which fixes the existence of history. Historically the first fixation was in Ancient Greece. Obviously we may discuss the question whether the ancient Greeks had a pronounced awareness of history and time (Collingwood), or not at all (Spengler), but we can fix the fact that Herodotus wrote the first book titled 'The History', and thus he has been considered the father of history. Another important fact is that Herodotus did not pursue ambitious objectives: he focused solely on saving the details of the Greco-Persian war from oblivion. So, the contextual investigation of time or the history of Greece was an absurd idea for the ancient Greeks. Since history was considered as a statement of certain events, for which no special skills are required. Hence, there was no need for a philosophy of history. Even such a comprehensive thinker as Aristo- tle has no philosophy of history. He thinks of history in his 'Poetics' while writing a comparison between history and poetry. "The poet and the historian differ not by writing in verse and in prose. The work of Herodotus might be put into verse, and it would still be a species of history, with meter no less than without it. The true difference is that one relates what has happened, the other what may happen. Poetry, therefore, is a more philosophical and a higher thing than history: for poetry tends to express the universal, history the particular" (Aristotle, 1902, p. 35). According to Aristotle, history relates about singular events which have nothing to do with the universal laws of existence. It is this circumstance that has served as a reason for Greek philosophers to ignore the history. And Plato, as Collingwood notes, "writes as if Herodotus had never lived" (Collingwood, 1992, p. 29). As long as the world had been manifested as a static one in human 
consciousness, history, as well as philosophy of history, could not have their 'honorable' place in the system of knowledge.

The situation changed when historism appeared in the nineteenth century. By historism I mean nothing more than some new principles which allow comprehending life in historical process. That is to say, history gradually gets ontological status: history is no longer merely a registration of some events. This change was due to a number of factors. First of all, we should mention that this change was prepared in various fields - epistemology, social philosophy, ethics, etc. For instance, to represent the process of recognition more fully and to save subject from solipsism the idea of cognitive autonomy was proposed in epistemology. The best demonstration of this idea was Hegel's doctrine. To understand the fundamental character of the idea of progress and revolutions as well in social philosophy, all discussions were moved to the context of historism. One needs historical approach in ethics to understand human visions, the idea of perfection, etc. It was a project in theory. "In practice, this was manifested by the emergence of history as an independent academic discipline" (Nadel, 1964, p. 291). Here we are talking about the necessity of the philosophy of history, about credible and/or non-credible philosophy in relation with history as an academic discipline. If previously there was no requirement for the philosophy of history, because the history was considered as a very simple thing, then there was really such a requirement after historism, but it was already difficult, if not impossible, to satisfy this requirement; inasmuch as history was thought as an universal phenomenon, its definitions would be very different. We can refer to dif- ferent definitions of history to show that historians disagree on this issue. Here are some of them.

"Those who consider History a simple aggregate of particular facts are mistaken. They practise the cumulation of particulars upon particulars, held together only by some moral principle. I believe rather that History is able to lift itself in its own fashion from the observation of particulars to a universal view of the events, knowledge of an objectively existing relatedness" (Leopold von Ranke) (see Pachter, 1974, p. 444).

"What I construct historically is the result of imagination, not of critical thought. Where there is no inner image, I cannot accomplish anything" (Jacob Burckhardt) (see The Letters of Jacob Burckhardt, 1955, p. 21).

"The science of History is the result of empirical perception, experience and investigation" (Johann Gustav Droysen) (Droysen, 1882, p. 8).

In order to resolve these disagreements theorists and philosophers of history have tried to build philosophy of history models to explain and guide the development of historical knowledge. As it is impossible to represent all known conception of philosophy of history within this paper, let us try to list them in classified form. We can talk about the theory of evolution (Hegel, Marx), the cyclical theories (Vico, Spengler, Toynbee), the positivist philosophy of history (Hempel), the analytical philosophy of history (Danto), etc. However these philosophies of history are also so different that it is difficult to specify one general philosophy 
of history. The very concept of philosophy of history was used in different ways from the start. It was Voltaire who for the first time gave the title philosophy of history to the history that is written in critical way. By philosophy of history Hegel understands reflective universal history; for Danto philosophy of history is a field where one analyses all sentences of the written history and determines its relevance. Accordingly, it is not well-defined the subject of the philosophy of history too. Of course, one can suppose that one of the existing doctrines is credible; nevertheless, counter arguments and mutual criticisms are so much in the literature that even a superficial glance would allow seeing that there is no accepted philosophy of history. Because of the need to speak briefly we cannot represent the history of the philosophy of history. So, we are satisfied with speaking of one conception that has been developed recently. I mean Hayden White's 'Metahistory' published in 1973.

According to White, historical narratives are called not to describe the past, but make possible to speak about the past. Historical narratives establish certain facts, that is, create opportunities to bridge the present with historical events. And the discipline that studies the linguistic tropes of those narratives White calls metahistory, in other words, history of historiography. His main attitude he represents as follows: 'In short, it is my view that the dominant tropological mode and its attendant linguistic protocol comprise the irreducibly "metahistorical" basis of every historical work' (White, 1973, p. xi). It means that every historical text includes also its metahistorical level, and therefore, every historical text is a manifestation of methods of philosophy of history. It is not accidental that White, from one hand, dedicated four chapters to historians Michelet, Ranke, Tocqueville, and Burckhardt, and, accordingly, four chapters to philosophers of history - Hegel, Marx, Nietzsche, and Croce, on the other hand, thus throwing a bridge between them. White distinguishes three major levels for determination of historical work in the nineteenth century - explanation by emplotment, explanation by argument, and explanation by ideological implication. At the first level White talk about four different modes of emplotment - Romance, Satire, Comedy, and Tragedy. The Romance is fundamentally a drama of selfidentification symbolized by the hero's transcendence of the world of experience, his victory over it. The Satire is, in fact, a drama of diremption, a drama dominated by the apprehension that man is ultimately a captive of the world and not its master. In Comedy, hope is held out for the temporary triumph of man over his world by the prospect of occasional reconciliations of the forces at play in the social world. Finally, in Tragedy, there are no festive occasions, except false and illusory ones (White, pp. 8-9). That is to say, the same events can be represented in different positions; in one case as a kind of final victory, as a temporary victory in the other case, as a frustration in the third case, etc. On the other hand, from a linguistic point of view, each historical text is formulated by one of these four basic tropes - Metaphor, Metonymy, Synecdoche, and Irony.

White hoped to remove all tropological and subjective components from historical text by metahistorical investigation and to discover pure historical knowledge. As a critical remark, we will highlight here only one item: White's text is also written by one of four 
tropes (in this case, by Irony), isn't it? So, how can we be sure that his survey is unprejudiced?

In addition, a question remains: to whom is the philosophy of history addressed? If it is written for historians, they hardly use it or even can use. And its direct use can lead to ridiculous situations. Here is such case: 'A teacher who asks his boys why the window is broken will not be satisfied with the answer: "Whenever a brittle object is hit by a hard missile at high speed, it will break (covering law); a baseball is a hard missile capable of breaking glass (inductive probability); hence the window broke." Even if the teacher should happen to be a logical positivist, he might angrily ask: "Who did it?" His colleague from History, who has observed the scene, may remark with a grin: "Professor Hempel is learning what history is about" (Pachter, 1974, pp. 440-441).

Historians, indeed, presuppose some philosophical theses, but as a rule, we discover them only post factum. The requirement to follow the philosophy of history limits historians' opportunities. And if the philosophy of history is for philosophers, then it is out of scopes of credible-noncredible. Since a philosophy of history can be credible only in relation with history. When we ask "Can a philosophy of history be credible?", we mean credible from the historians' or history's point of view.

If we pay attention to human activity, we will see that they are mostly utopian intensions. Perhaps we can agree with Ortega y Gasset's statement that "everything that Man does is utopian" (Ortega y Gasset, 1992, p. 103). Indeed, in fact, what we do, we do not succeed entirely; cognition, love, happiness, peace are utopian phenomena, aren't they? Especially because there is no algorithm to obtain them; they are rather dreams. And isn't the credibility of philosophy of history utopian from this point of view? What, ultimately, does mean credibility for philosophy of history? It supposes an academic discipline whereby historians can write an adequate or perennial history. While answering to this question there is another one: is there any credible thing? Is history credible? Still even the subject matter of historical science is not certain; what is about the history: is it about human being, or culture, or spirit, or society, or national state, or anything else?

On the other hand, the philosophy of history as a discipline was established earlier than the history. Until the nineteenth century history was not taught as an academic discipline in European universities, moreover, there was no any faculty of history. It was believed that history could not be a science. However, philosophers had discussed some issues of the philosophy of history prior to the nineteenth century. Now, is it correct to put that question in connection with the philosophy of history par excellence?

We should understand one simple thing: "When we speak, we are humble hostages to the past" (Ortega y Gasset, p. 108). This applies to historians par excellence. Historians are humble hostages to the past both because of language and the subject matter - past. Hence, the historian is not free while recording the history. It is usually difficult to identify the main principle of history writing: does historian record the events? Which events does he particularly record? Does he record chance events too? The historian, in the end, deals not 
with the events (because they do not exist as things themselves), but with mind that thinks of events. As Collingwood writes, "Unlike the natural scientist, the historian is not concerned with events as such at all. He is only concerned with those events which are the outward expression of thoughts, and is only concerned with these in so far as they express thoughts" (Collingwood, 1992, 217). The history is not given to us directly, and historical narrative is not a simple protocol. The historian and the history do exist due to each other. "The historical process is itself a process of thought, and it exists only in so far as the minds which are parts of it know themselves for parts of it" (Collingwood, p. 226). So, this means that the cooperation of the philosophy of history and the history is mutually beneficial. Finally, we can state that the philosophy of history is not credible in positivist sense, i.e. there are no certain formulations for historical research, but it makes life more meaningful. The philosophy of history "is more a matter of the worldview than of historical research" (Troeltsch, 1922, p. 11). It transmutes the past into the present, makes the future more predictable, and thus makes possible to grasp the whole historical time. To write a philosophy of history means to break through the limits of self-knowledge, to take part in the emergence of the history, and to outline dreams for those people who think of the future. To write a philosophy of history means to give a man an opportunity to live with a dream. Isn't it the true credibility?
When a father educates his son to survive, one cannot predict successful destiny for a child, though as a parent father hopes so; however, how sad it would be without father's advices!

\section{REFERENCES}

Aristotle. (1902). Poetics. (3rd ed.) The Macmillan Company.

Collingwood, R. G. (1992). The Idea of History. Oxford University Press.

Droysen, J. G. (1882). Grundriss der Historik. Leipzig.

Nadel, G. H. (1964). Philosophy of History before Historicism. History and Theory, 3(3), 291-315.

Ortega y Gasset, J. (1992). The Misery and the Splendor of Translation. Theories of Translation: an Anthology of Essays from Dryden to Derrida, 93-112. The University of Chicago Press.

Pachter, H. M. (1974, Autumn). Defining an Event: Prolegomenon to Any Future Philosophy of History. Social Research, 41(3), 439-466.

The Letters of Jacob Burckhardt (1955). (A. Dru, Trans.) London: Routledge and Kegan Paul.

Troeltsch, E. (1922). Der Historismus und seine Probleme. Tübingen.

White, H. (1973). Metahistory. The Historical Imagination in Nineteenth-Century Europe. The Johns Hopkins University Press. 